\title{
A Computational System for Monitoring Landslide Risk Based on TerraMA2
}

\author{
Um Sistema Computacional de Monitoramento de Riscos de Deslizamentos \\ baseado no TerraMA2
}

\author{
Ricardo Cabette Ramos ${ }^{1}$ \\ Marconi Arruda Pereira ${ }^{2}$ \\ Tales Moreira Oliveira ${ }^{3}$ \\ Heraldo Nunes Pitanga 4
}

Recebido em abril de 2018.

Aprovado em novembro de 2018.

\begin{abstract}
The intensity to which natural phenomena have been occurring and surprising the population imposes on Engineering the search for preventive measures that minimize the contingent of people affected by these tragedies. It happens due to the imminent risks of disasters, posed by rain combined with the soil properties, declivity and the type of land use and land cover existing in the region. From this perspective, an experimental program aimed at issuing warnings is justified from the technological point of view. Therefore, the present work presents an elaboration of a monitoring system to analysis and alert generation of risks for the city of Ouro Preto MG, based on TerraMA2. The project used for the elaboration of analysis models precipitation data obtained by data control points and by hydroestimator. In additionit was used a case study with 33 occurrences of slope disruption in the city of Ouro Preto. The obtained results showed that the generated model would be effective to identify imminent risk situations.
\end{abstract}

KEYWORDS: Landslide. TerraMA2. Risk analysis.

\footnotetext{
${ }^{1}$ Federal University of São João del-Rei (UFSJ). Department of Technology of Civil Engineer, Computer and Humanities, Brasil.

E-mail: ricardo.cabette@outlook.com

${ }^{2}$ Federal University of São João del-Rei (UFSJ). Department of Technology of Civil Engineer, Computer and Humanities, Brasil.

E-mail: marconi@ufsj.edu.br

${ }^{3}$ Federal University of São João del-Rei (UFSJ). Department of Technology of Civil Engineer, Computer and Humanities, Brasil.

E-mail: tales@ufsj.edu.br

${ }^{4}$ Federal University of Viçosa (UFV). Department of Civil Engineering.

E-mail: heraldo.pitanga@ufv.br
} 


\begin{abstract}
RESUMO
A intensidade com que os fenômenos naturais vêm ocorrendo e surpreendendo a população impõe à Engenharia a busca por medidas preventivas que minimizem o contingente de pessoas afetadas por essas tragédias. Nessa perspectiva, justifica-se, do ponto de vista tecnológico, um programa experimental que vise à emissão de alertas, devido aos riscos iminentes propiciados pelas chuvas que, aliadas às propriedades do solo, declividade e o tipo de uso e ocupação existente na região, impulsionam a ocorrência de desastres. Assim sendo, o presente trabalho se presta a promover a elaboração de um sistema de monitoramento, análise e alerta de riscos para a cidade de Ouro Preto - MG, através do software TerraMA2. O projeto utilizou para elaboração dos modelos de análises, dados de precipitações provenientes de Pontos de Coleta de Dados e de um hidroestimador. Além disso, utilizou-se como estudo de caso 33 ocorrências de rompimento de encostas na cidade de Ouro Preto. Os resultados demonstraram que os modelos gerados seriam eficazes para identificar previamente situações de risco.
\end{abstract}

PALAVRAS-CHAVE: Deslizamento. TerraMA2. Análises de risco.

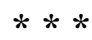

\title{
Introduction
}

Natural disasters have affected human survival since the beginning of times, due to the intense and numerous types of destruction they cause. The problems of significant numbers of casualties and damage to property and to the economy have contributed to a greater focus on this issue. Dias, Fonseca and Coutinho (2006) suggests that these events have generated significant numbers of casualties and have also caused significant losses, related to the destruction of buildings. Dias, Fonseca and Coutinho (2006) also states that, according to the United Nations, mass movement is a damaging catastrophe only inferior to earthquakes and floods among natural phenomena that most impact humanity.

Lopes, Namikawa and Reis (2011) define the process of sliding of gravitational mass, which generally occurs when a strand already saturated with water is achieved by an intense precipitation. They also point out that the process is induced by climatic, hydrological, geological, geomorphological factors, the vegetation and also by humans. 
Regarding these mass movement processes, weather is highlighted as the precursor of these incidents. According to Wolle (1988), the climate is characterized as a potentiating agent because of instability of slopes and also the immediate cause of breaking slopes, usually due to heavy rains. Lopes, Namikawa and Reis (2011) point out that rain interferes with the safety of slopes, favoring an increase in the specific weight of the soil, minimizing the cohesion and internal friction angle of the material, and promoting the formation of a water level (NA) that creates parallel streams to the hillside, with the same direction of shear stress.

Brazil is one of most affected countries by climate disasters (ONUBR, 2016). According to the United Nations Office for Disaster Reduction (UNISDR) and the Centre for Research and Epidemiology of Disasters (CRED), Brazil is the only country in the Americas on the list of 10 countries with the highest number of people affected by disasters between the years 1995 and 2015. In these two decades, about 51 million Brazilians have been affected by disasters (ONUBR, 2016).

Thus, a system of monitoring, analysis, and risk alerts through mathematical-computational models is justified. In order to do so, it was necessary to construct a computational framework that would be able to bring together the different sources of data already existent, allying other local information that could be processed, providing gradual alerts that increase their level as the situation becomes increasingly serious.

From this perspective, this work had as general objective the development of a system of monitoring, analysis, and alert of real risks of landslides using rain measured from different sources. The system implements an analysis model for different districts of the city of Ouro Preto, calibrated according to the specific characteristics of such to which the model refers. Based on this premise, we have specific objectives like the elaboration and calibration of a risk analysis model for slopes and barriers, the development of monitoring mechanisms for excess rainfall, as well as the design of different levels of alerts, according to the geographic region's 
setting. This mechanism is intended to generate warnings in a timely manner so that the responsible authorities as well as the community leaders can take appropriate action to mitigate potential damages to the communities concerned.

Ramos et al. (2017) developed the first analyzes of this research. This new work presents an evolution of the results obtained, now using the precipitation data of a Data Control Point (DCP) and from a hydroestimator. DCP is rainfall data acquired from in situ measurements, such as pluviometers. Regarding the hydroestimator, the measurements come from the Goes satellite precipitation data. Thus it was possible to make new analysis models and generate different maps of risk alerts.

\section{$1 \quad$ Related work}

Barbosa et al. (2014) developed studies using the Meteosat Second Generation (MSG) satellite data. According to the author, these data are received in almost real time, are easy to use and have a low cost of terrestrial reception. The ingest of these data was processed using the McIDAS-V, ILWIS and TerraMA2 tools. The results pointed to a high potential of application of these tools, and presented the possibility of data from MSG being combined with other data in order to perform different analyzes.

Segoni, Piciullo and Gariano (2018), carried out a study on landslide early warning systems, including monitoring systems, rainfall thresholds, warning models, performance evaluation and risk perception. The author stresses the importance of defining certain variables to be measured and monitored, given the type of landslide and the scale of analysis. It also emphasizes the need for an effective communication system and emergency plans. From his considerations, it is noted that TerraMA2 is a tool of high potential, since it was able to contemplate the different topics addressed by the author. 
Piciullo, Calvello and Cepeda (2018), made a bibliographical survey regarding territorial early warning systems for rainfall-induced landslides. In this study he presents two categories of landslide risk alerts systems, local and regional. In his research the author praises the regional systems and notes the increasing adoption of these as a form of landslide risk mitigation. In addition, the author discusses the importance of reliability analysis of the system and the need to continually feed the database in order to have a permanent evaluation of the performance of the system.

Intrieri et al. (2012) propose a set of techniques to be used as a warning system for a given region that suffers from the hazard of soil slip. This study covers several components. Among the most relevant ones are: the geological characterization, risk scenarios and defining the most appropriate level of alarm. Through this type of monitoring, it is sought to predict, as realistic as possible, the risk of collapse of an area, informing the users. However, this research is guided by techniques that have a relatively high implementation cost, due to the need of specific devices for the system.

Dai and Lee (2001) present a study relating rainfall to landslides in Hong Kong, that is a region characterized with high steepness. Through a historical research, a study was made which shows the volume of earthworks with rainfall intensity, establishing a frequency of occurrence of such event. However, it was not discussed in this work any mitigation technique of these events, or even any risk warning system.

Salciarini et al. (2008) develop a research directed to establish where and when the risk of landslides in Seattle, USA can occur. For this, they took into account different recurrence times, rainfall durations, properties of embankments, among other factors. The product of this study can be summarized in a map that shows the probability of recurrence of events that cause such disasters.

Lopes, Namikawa and Reis (2011) present a survey guided in monitoring and risk alert through SISMADEN software (Monitoring System and Natural Disaster Alert) in which the slope is considered the main factor 
of landslides. By monitoring these areas and through the data of rainfall estimates in real time, it is possible to alert the probability of events, such as those that occurred in Angra dos Reis, Brazil and neighboring municipalities, in December 2009.

Reis (2014) propose monitoring and alert in advance to extreme events that may occur in the metropolitan region of São Paulo, Brazil. For this, they used the SISMADEN software. They also used hydro meteorological basis and nowcasting which allow short-term forecasts. Other tools used were FORTRACC and HYDROTRACK that identify distribution, the development and the transportation of rainfall. However, the results found by HYDROTRACK were not satisfactory, thus requiring further analysis.

Reis, Cordeiro and Lopes (2011) propose a new monitoring and risk warning system through SISMADEN software. For this research, it was used the hydro meteorological satellite data, registries from data control points (DCP) and numerical weather prediction - ETA model. As a result, it was possible to identify the risks of extreme events with approximately 18 hours in advance, which would help in the decision-making process of the Civil Defense.

The Earth System Science Center (2015), shows a study on the risk of landslides in the São Paulo region, Brazil. The relevant factors of the analysis relate to the understanding of the land use and land cover, the high potential of precipitation, with its time of recurrence, and relief features. This diagnosis was supported by IPT experts (Technological Research Institute) that predicted the potential for ground handling risk in the region. By overlaying these elements, there was provided a slip threat model, which resulted in a map of levels of collapsing risk.

Among the several research and data studied, there are some documents that present the development of risk analysis of certain regions and later present some kind of alert to the population of interest. However, these surveys do not include regions that are in need, suffering intensely from 
catastrophic events due to natural phenomena and victimizing thousands of people. Furthermore, the purpose of this research is to carry out a large-scale system of monitoring, analysis, and alert of risks, in regions that are affected by geological accidents; in a way that the alert system is of easy control, easy access to the people, and also is as close as possible to reality.

\section{$2 \quad$ Methodology proposal}

The study area chosen for the development of the research was the municipality of Ouro Preto, as shown in Figure 1.

Figure 1-Map of counties of the municipality of Ouro Preto.

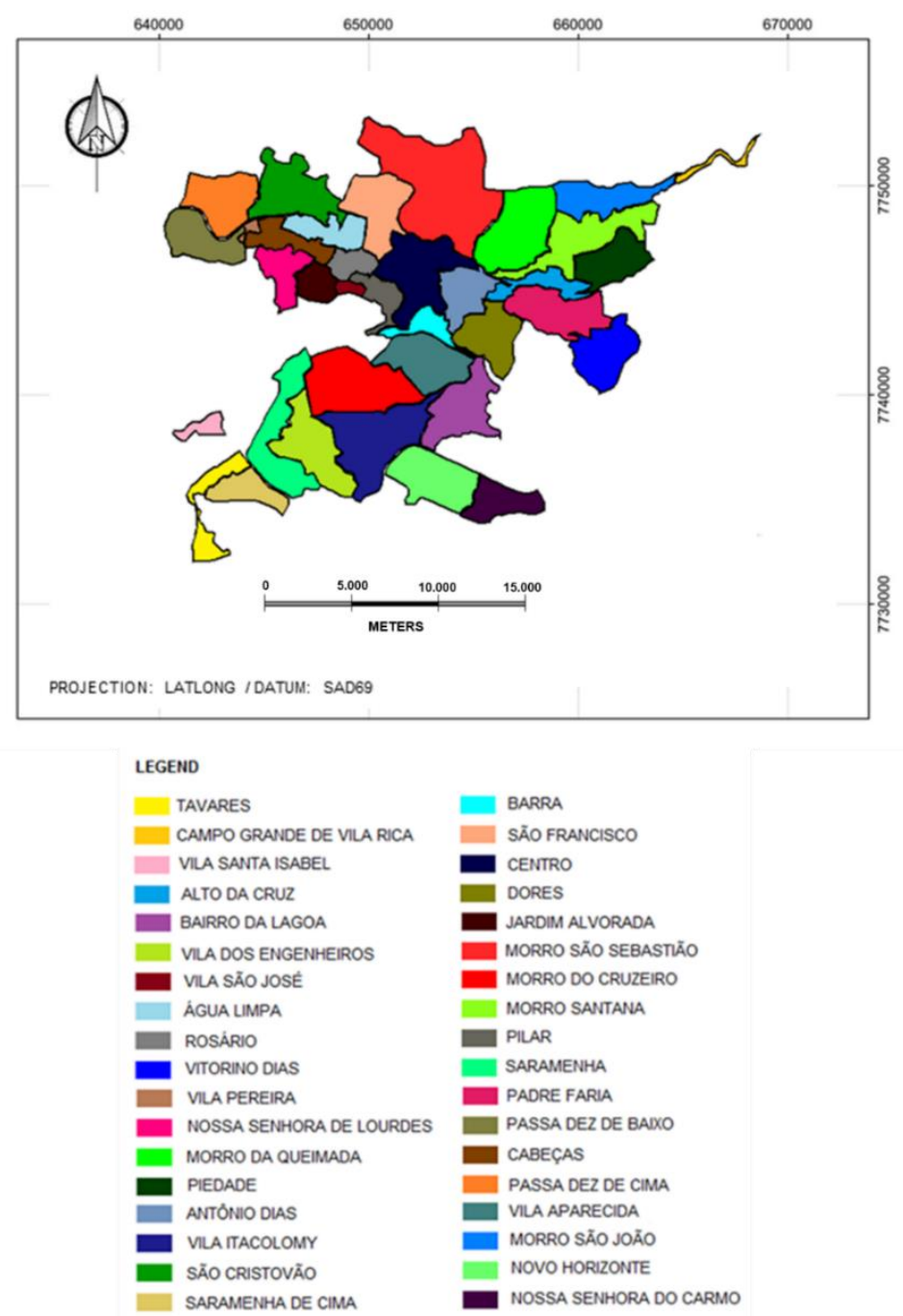

Source: Elaborated by the authors.

Rev. Bras. de Cartografia, vol. 70, Special Issue "XIX Brazilian Syposium on

GeoInformatics", 2018. pp. 1823 - 1843. 
The municipality of Ouro Preto was the case of study due to the geological risks related to mass movement and also because the Civil Defense and the Municipal Government of Ouro Preto made available the data collection of the municipality. In this perspective, the considerable riskincrease in these areas, over the years, is highlighted, mainly with a disorganized occupation. Faced with this prerogative, surveys were made of events occurred in this municipality between 2005 and 2012, and the results were from heavy rains. During this period, the cumulative rainfall in the defined region reached above $128 \mathrm{~mm}$ of rain on five consecutive days, which according to Black Gold Meteorological Alert System (SAMOP) the probability of occurrence of more severe accidents increases (PREFEITURA DE OURO PRETO, 2016).

\section{$2.1 \quad$ Materials}

In the execution of this research TerraMA2 software (http://www.terrama2.dpi.inpe.br/) was used for the development of the monitoring system, analysis, and alerts of risks. The proposal of this tool is to create a system that exposes environmental information related to climatic and hydro-meteorological extremes to the mapping of areas with great potential for risk. In this context, it is expected that the intersection of all data will allow high-risk situations to be identified. Based on this premise, there is a need to insert hydro-meteorological data on the platform. Such data is provided by institutes such as CPTEC / INPE (INPE, 2015). For this research, the city of Ouro Preto provided rainfall data regarding Data Control Points (DCP) in the regions studied, between November 2005 and January 2012, and CPTEC / INPE (INPE, 2015) provided satellite precipitation data (Hydroestimator). With regard to the DCP, this is an element of the program that was installed in the city of Ouro Preto (Latitude: $20^{\circ} 18^{\prime} 11^{\prime \prime}$ South; Longitude: 43 $36^{\prime} 57^{\prime \prime}$ West). The Hidroestimator corresponds to a precipitation of $\mathrm{mm} / \mathrm{h}$, obtained from the GOES satellite. The resolution of 4 
$\mathrm{x} 4 \mathrm{~km}$ and each collective file corresponds to a single numerical grid in binary format.

Tied to these environmental data, static data was introduced from the region of interest, which consists of the lithological map, slope, land use and land cover, as well as the map of neighborhoods, all provided by the city of Ouro Preto. Regarding the calibration of the system, 33 occurrences of landslide slopes of the municipality of Ouro Preto, made available by the Civil Defense of the municipality, were analyzed as shown in Figure 2.

Figure 2-Map of occurrence of mass movement.

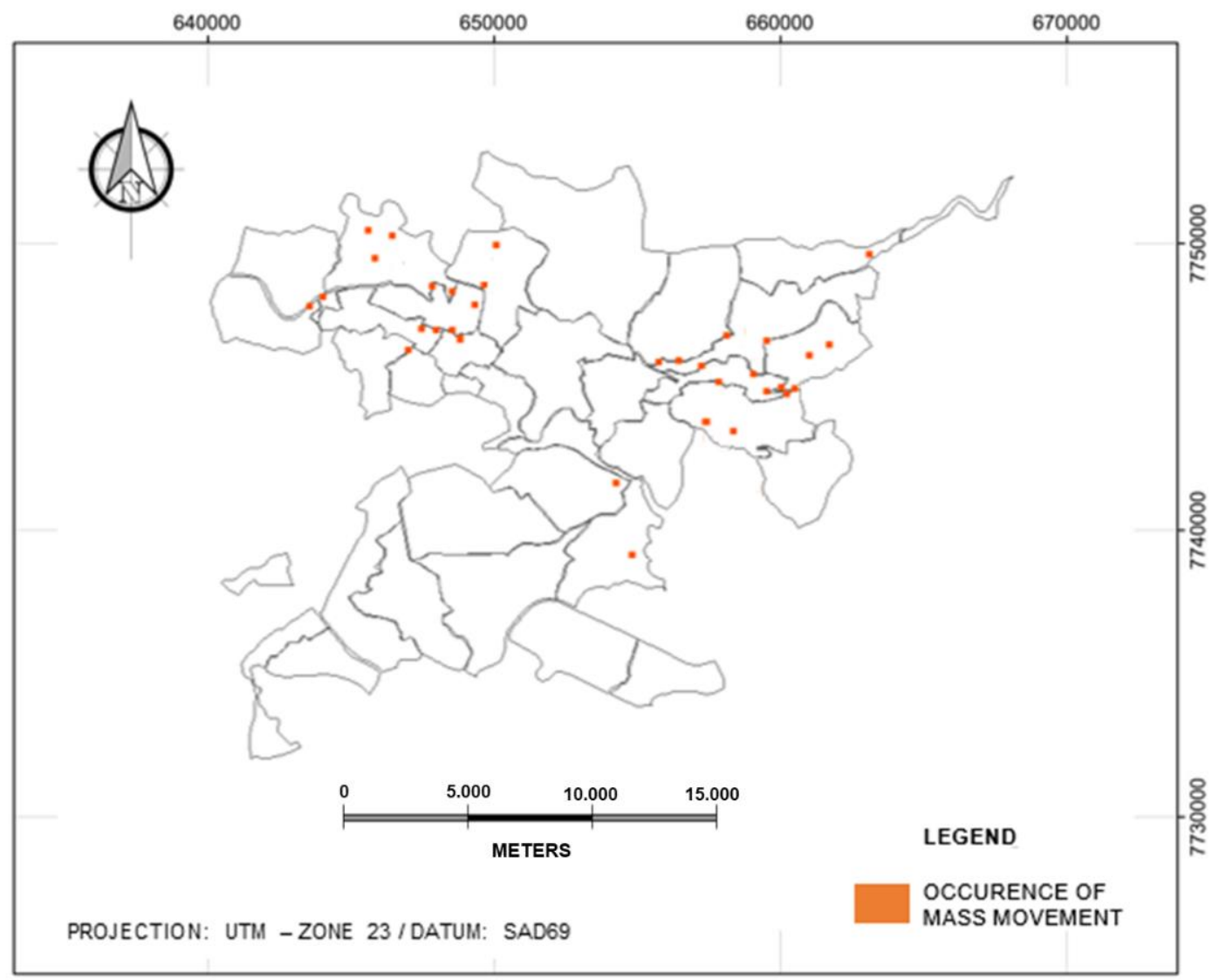

Source: Elaborated by the authors.

\subsection{Methods}

According to Reis, Santos and Lopes (2011), the TerraMA2 platform basically has the function to look for data from different servers and associate them in a database with the purpose to perform the analysis' 
models, and for each new data collected and entered in the database is performed further analysis to assess whether it is or not a risk. From this premise, if a threat is identified, a warning signal is generated.

In the execution of this work two types of data were used, the dynamic environmental data and the static data, the later related to the geographic object monitored, i.e. municipality of interest. In relation to the dynamic environmental data, precipitation values collected by DCP and by hydroestimator

The data from the monitored object refer to the existing lithology, the land use and land cover map and the slope of the city of Ouro Preto. Soil is one of the determining factors of the land vulnerability regarding the movements and possible accidents (DIAS, FONSECA and COUTINHO, 2006), which combined with the slope of the region, the type of land use and land cover contribute markedly to the collapse of soil masses. Through TerraView these maps are combined to generate a database, which will be used as subject of study.

Subsequently, the risk analysis model is developed in TerraMA2 platform. The model was calibrated from the study and analysis of ten periods between the years 2005 to 2012 , being 5 of these periods without occurrence of events and 5 with occurrences of mass movement. These respective periods analyzed are shown in Table 1.

The purpose of this whole apparatus is to perform several tests in order to calibrate the system. Depending on the type of present risk, TerraMA will offer different alert levels. Based on SAMOP in Table 2 the alert levels provided by TerraMA ${ }^{2}$ that were used in the study (PREFEITURA DE OURO PRETO, 2016), plus a new sign, the 'without warning', in order not to be issued irrelevant alerts. 
Table 1 - Analysis periods for system calibration.

\begin{tabular}{c|c|c}
\hline Analysis & Occurrences & Period \\
\hline 1 & There have been & $01 / 11 / 2005$ to $31 / 12 / 2005$ \\
\hline 2 & There have been & $01 / 12 / 2006$ to $31 / 01 / 2007$ \\
\hline 3 & There have been & $01 / 01 / 2009$ to $30 / 02 / 2009$ \\
\hline 4 & There have been & $01 / 01 / 2011$ to $30 / 02 / 2011$ \\
\hline 5 & There have been & $01 / 12 / 2011$ to $31 / 01 / 2012$ \\
\hline 7 & There were no occurrences & $01 / 07 / 2005$ to $30 / 08 / 2005$ \\
\hline 9 & There were no occurrences & $01 / 04 / 2006$ to $05 / 30 / 2006$ \\
\hline 10 & There were no occurrences & $01 / 01 / 2008$ to $30 / 02 / 2008$ \\
\hline
\end{tabular}

Source: Elaborated by the authors.

Table 2 - Alert levels used and available by TerraMA2.

\begin{tabular}{c|c|c}
\hline \multicolumn{3}{c}{ Alert levels } \\
\hline 1 & & No alert \\
\hline 2 & $\mathbf{A}$ & Note \\
\hline 3 & $\mathbf{A}$ & Attention \\
\hline 4 & $\mathbf{4}$ & Alert \\
\hline 5 & $\mathbf{4}$ & Maximum alert \\
\hline
\end{tabular}

Source: Elaborated by the authors.

\section{$3 \quad$ Experiments and results}

With regard to the construction of this project, it is emphasized that all the maps used in this research were acquired through the data collection of the Ouro Preto City Hall, this being a lithological map of slope and of land use and land cover, as well as the counties' map. Through the TerraView software, an intersection between the region of interest and the maps was performed, resulting in maps of the studied region.

In relation to the declivity map, a striped division was made according to the existing slope level. Weight was also inserted at these levels. Table 3 shows the slope intervals and the weights assigned to them. 
Table 3 - Weight of slope.

\begin{tabular}{c|c|c}
\hline Declivity & Classification & Weighting \\
\hline $0-10 \%$ & 1 & 0,025 \\
\hline $10-20 \%$ & 2 & 0,125 \\
\hline $20-40 \%$ & 3 & 0,625 \\
\hline $40-60 \%$ & 4 & 0,875 \\
\hline $60-100 \%$ & 5 & 1,000 \\
\hline$>100 \%$ & 6 & 1,200 \\
\hline
\end{tabular}

Source: Elaborated by the authors.

In relation to lithology, an analysis was made to determine how much this is favorable to erosive processes (Table 4). Thus, after a careful study of each lithology present, a weight was assigned to each type. It should be noted that this weighting underwent several adjustments so that it was calibrated and consistent with the events that occurred.

Regarding the land use and land cover map, an analysis of the region was carried out and, depending on the type of land use and land cover, weight was also attributed to them. Table 5 shows how the process of weighting was done.

In order to obtain the best calibration for the system, several tests were performed on the TerraMA ${ }^{2}$ platform. In addition to this process, the alert levels were defined, and 5 alert levels were used. Being these characterized as follows:

a) Level 0: No Alert - At this level there is no probability of occurrence of events;

b) Level 1: Observation - At this level constant meteorological monitoring is done;

c) Level 2: Attention - At this stage the Municipal Contingency Plan is started, with monitoring of rainfall indexes and meteorological bulletins issued by state and federal agencies;

d) Level 3: Alert - This level is characterized by prolonged rains and requires greater monitoring of rainfall indices and meteorological data that are issued by state and federal agencies; 
e) Level 4: Maximum Alert - This level is characterized by prolonged rains and forecast of continuity for the next days. This situation requires careful monitoring of the rainfall indexes and meteorological bulletins issued by state and federal agencies.

Table 4 - Weighting of lithology.

\begin{tabular}{|c|c|c|}
\hline $\begin{array}{l}\text { Lithology } \\
\end{array}$ & Classification & Weighting \\
\hline $\begin{array}{l}\text { Carbonate-quartz-feldspar-biotite-chlorite } \\
\text { shale, sericite-biotite-chlorite-quartz shale, } \\
\text { quartz-chlorite shale, cacissylic rock, } \\
\text { metaconglomerate and iron formation }\end{array}$ & 1 & 0,125 \\
\hline Diabásio & 1 & 0,125 \\
\hline $\begin{array}{c}\text { Quartzite with conglomerate lenses and } \\
\text { filito }\end{array}$ & 1 & 0,125 \\
\hline Quartzite, phyllite, some conglomerate & 1 & 0,125 \\
\hline $\begin{array}{l}\text { Quartzite, phyllite, quartz-sericite shale } \\
\text { and conglomerate }\end{array}$ & 1 & 0,125 \\
\hline $\begin{array}{c}\text { Quartz-mica-chlorite shale, chlorite shale, } \\
\text { biotite-mica feldspathic shale, local iron } \\
\text { formation }\end{array}$ & 1 & 0,125 \\
\hline $\begin{array}{l}\text { Metavulcanic rocks, green shale, chlorite } \\
\text { shale, phyllite and quartzite, with } \\
\text { conglomerate lenses }\end{array}$ & 1 & 0,125 \\
\hline Canga: limonitic capping & 2 & 0,375 \\
\hline $\begin{array}{l}\text { Dolomite, magnesium limestone and } \\
\text { dolomitic itabirite, with phyllite and } \\
\text { quartzite }\end{array}$ & 2 & 0,375 \\
\hline $\begin{array}{c}\text { Filito, dolomitic phyllite, dolomite; } \\
\text { Quartzite and subordinate iron formation }\end{array}$ & 2 & 0,375 \\
\hline Graphite shale, shale mica and phyllite & 2 & 0,375 \\
\hline $\begin{array}{l}\text { Graphite shale, mica schist, phyllite and } \\
\text { some quartzite }\end{array}$ & 2 & 0,375 \\
\hline $\begin{array}{c}\text { Laterite, bauxite and uncemented } \\
\text { ferruginous detritus }\end{array}$ & 2 & 0,375 \\
\hline Quartzite & 2 & 0,375 \\
\hline Talus: slip lands; Rock fragments with soil & 3 & 0,625 \\
\hline Alluvium: sand, clay, and gravel & 4 & 0,875 \\
\hline Itabirito & 4 & 0,875 \\
\hline Itabirito, phyllite and dolomitic itabirite & 4 & 0,875 \\
\hline Itabirito, phytic and dolomitic itabirite & 4 & 0,875 \\
\hline $\begin{array}{c}\text { Ferruginous quartzite, silver phyllite, } \\
\text { sericite shale }\end{array}$ & 4 & 0,875 \\
\hline
\end{tabular}

Source: Elaborated by the authors.

Rev. Bras. de Cartografia, vol. 70, Special Issue "XIX Brazilian Syposium on

GeoInformatics", 2018. pp. $1823-1843$. 
Table 5 - Weighting of types of land use and land cover.

\begin{tabular}{c|c|c}
\hline Land use and land cover & Classification & Weighting \\
\hline Commercial area & 1 & 0.875 \\
\hline Dense forest area & 2 & 1,000 \\
\hline Area of undergrowth & 3 & 0.625 \\
\hline High standard residential area & 1 & 0.875 \\
\hline Standard low residential area & 1 & 0.875 \\
\hline Average residential area & 1 & 0.875 \\
\hline
\end{tabular}

Source: Elaborated by the authors.

Within this perspective, two analytical models written in LUA were created, one referring to data from the hydroestimator and another from DCP. Both were elaborated based on data accumulated in 24 hours of rainfall. The codes are available in (https://github.com/ricardocabette/project rbc).

After completing all system configurations and setting all input parameters, the program was tested in order to check its warning alerts. This study was implemented for the ten periods, mentioned in Table 1. Figure 3, 4, 5 and 6 show the images generated by the system. In Figure 3 and 5, there is an imminent risk of slope deflagration, in which two mass movement events occurred. In figures 4 and 6, alert maps are presented, in which there was no recorded catastrophic event of any kind.

Considering the maps shown in Figures 3 and 5 it is possible to verify that the red alert matchs with incidents occurred in the municipality of Ouro Preto, as presented in Figure 2. This matching was verified for all 33 events, in which there were deflagrations of slopes. This shows that the calibration of the system presented a satisfactory result, considering the incidents occurred. The calibration of the System, it must be pointed out, was performed empirically, in which distinct analyses were obtained converging to the incidents occurance. The other neighborhoods also received maximum alerts due to high rainfall incidents. It is important to highlight that an incident can be occurred in this neighborhood, but may not have come to the attention of civil defense or was not relevant enough to be recorded.

It is also important to observe that the whole red region (level 4 of alert) presents imment risk of landslide, which is in compliance with the declivity 
of the region and the lithology of the soil combined with the accumulated rain level of $128 \mathrm{~mm}$ in 5 consecutive days, as presented by SAMOP (PREFEITURA DE OURO PRETO, 2016).

Figure 3 - Alert Map for 11/12/2005, considering the data of precipitation by DCP.

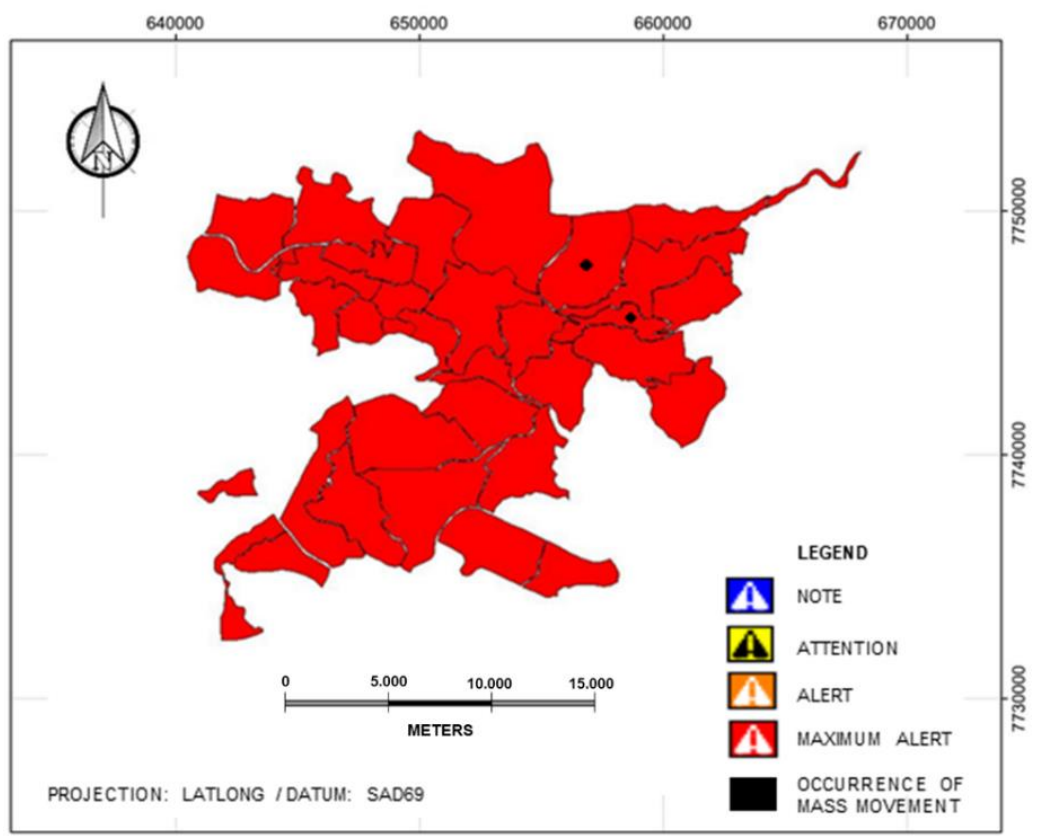

Source: Elaborated by the authors.

Figure 4 - Alert Map for 18/01/2012, considering the data of precipitation by DCP.

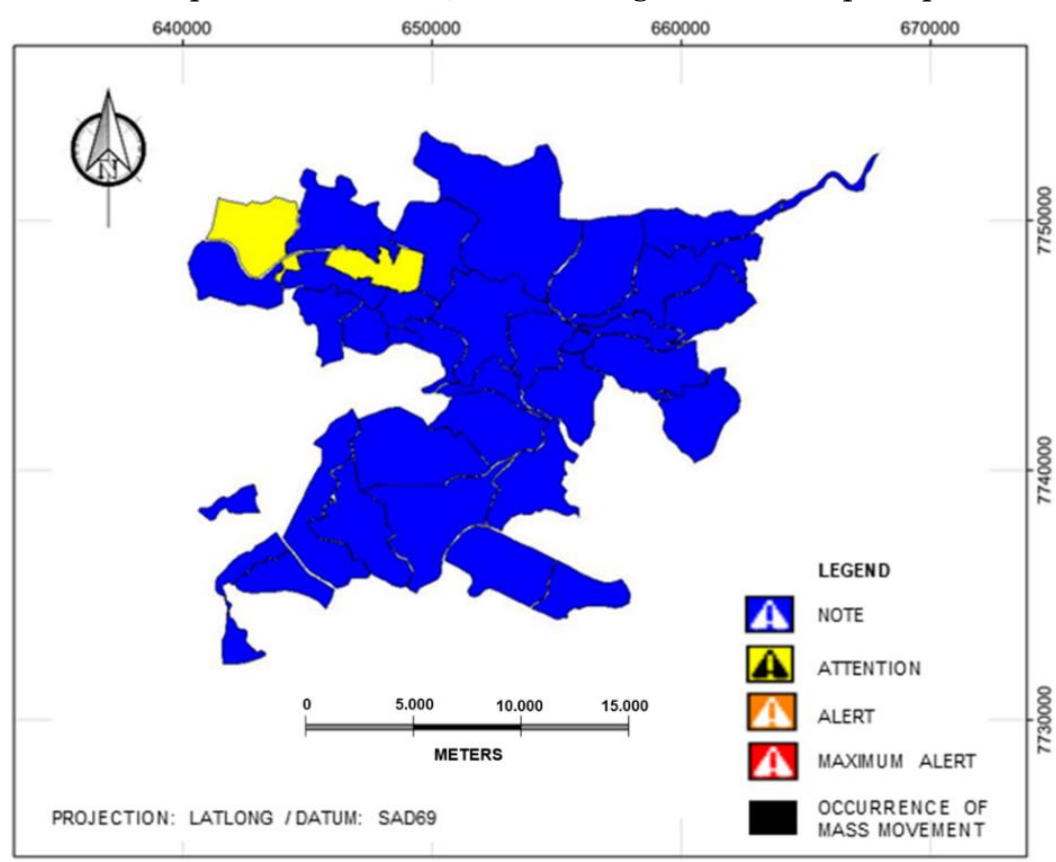

Source: Elaborated by the authors.

Rev. Bras. de Cartografia, vol. 70, Special Issue "XIX Brazilian Syposium on

GeoInformatics", 2018. pp. 1823 - 1843. 
Figure 5 - Alert Map for 11/12/2005, considering the data of precipitation by Hydroestimator.

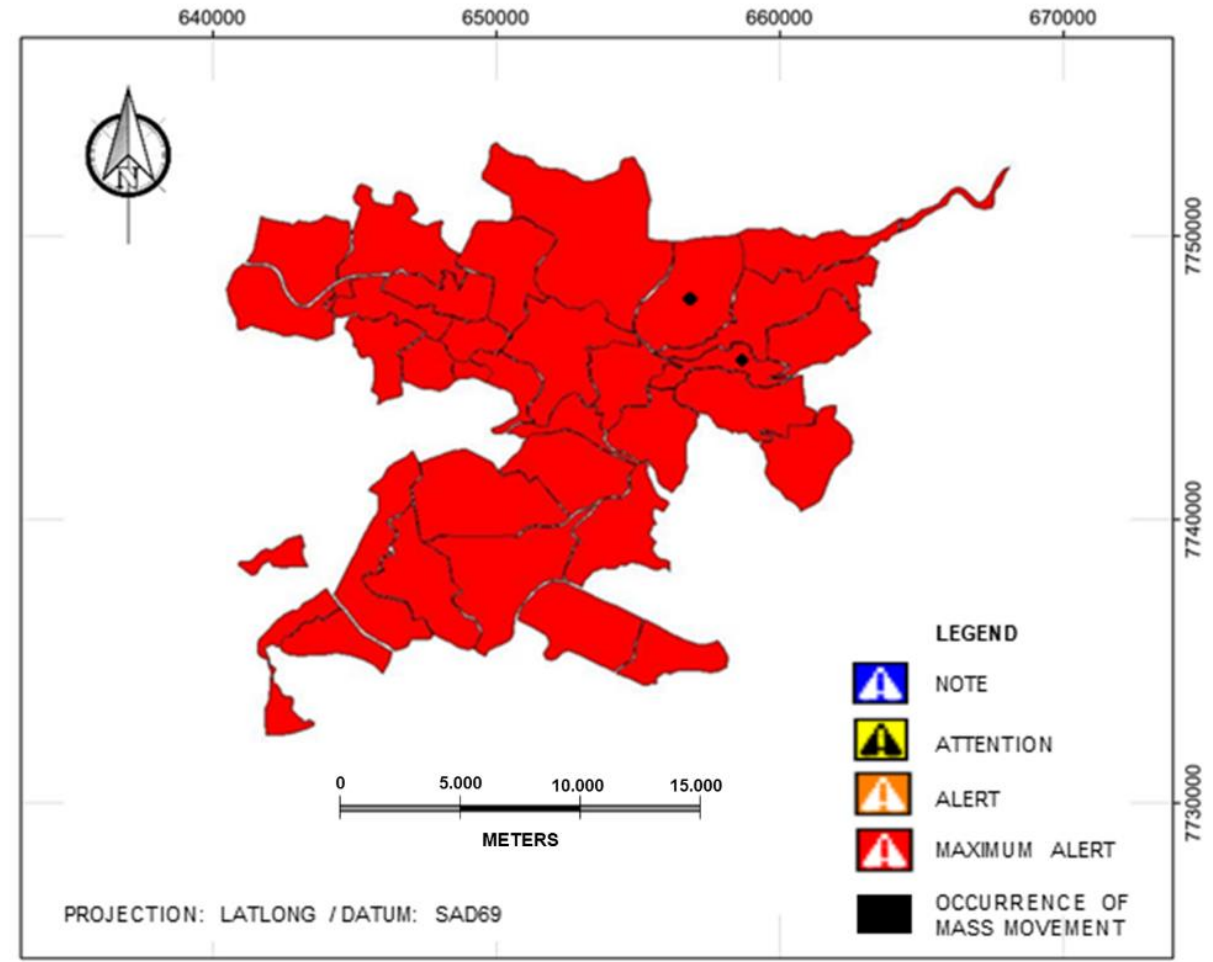

Source: Elaborated by the authors.

Figure 6 - Alert Map for 18/01/2012 considering the data of precipitation by Hydroestimator.

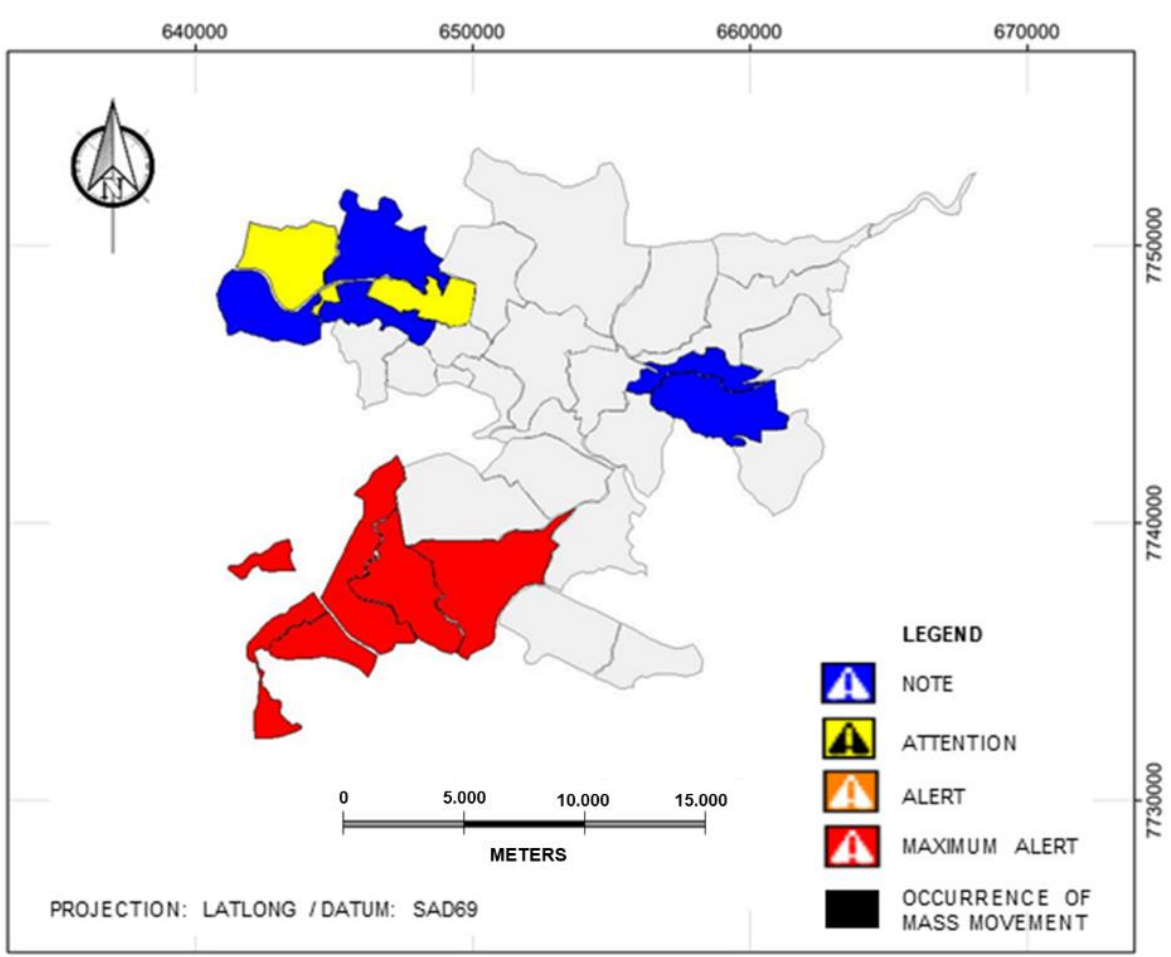

Source: Elaborated by the authors.

Rev. Bras. de Cartografia, vol. 70, Special Issue "XIX Brazilian Syposium on

GeoInformatics", 2018. pp. 1823 - 1843. 
It should be noted, however, that the maps generated by the analysis models using data from the hydroestimator can lead to significant falsepositive rates. This fact was noticed in some analyzes carried out, in different periodicities. This result can be justified by the fact that the precipitation data resolution of the hydroestimator is very broad when compared to the area under study. This problem can be seen in Figure 7.

Lopes, Namikawa and Reis (2011), have developed a study concerning the landslides in the cities surrounding Angra dos Reis (RJ). In this study, Hydroestimator data were used. The authors successfully integrated the Hydroestimator data with the ETA model - a numerical prediction model with $5 \times 5$ resolution - and were able to perform a precipitation estimate. However, the authors emphasize that it is important to make use of other data sources, such as meteorological radars, a denser pluviometric network and others in order to bring more reliability to the system.

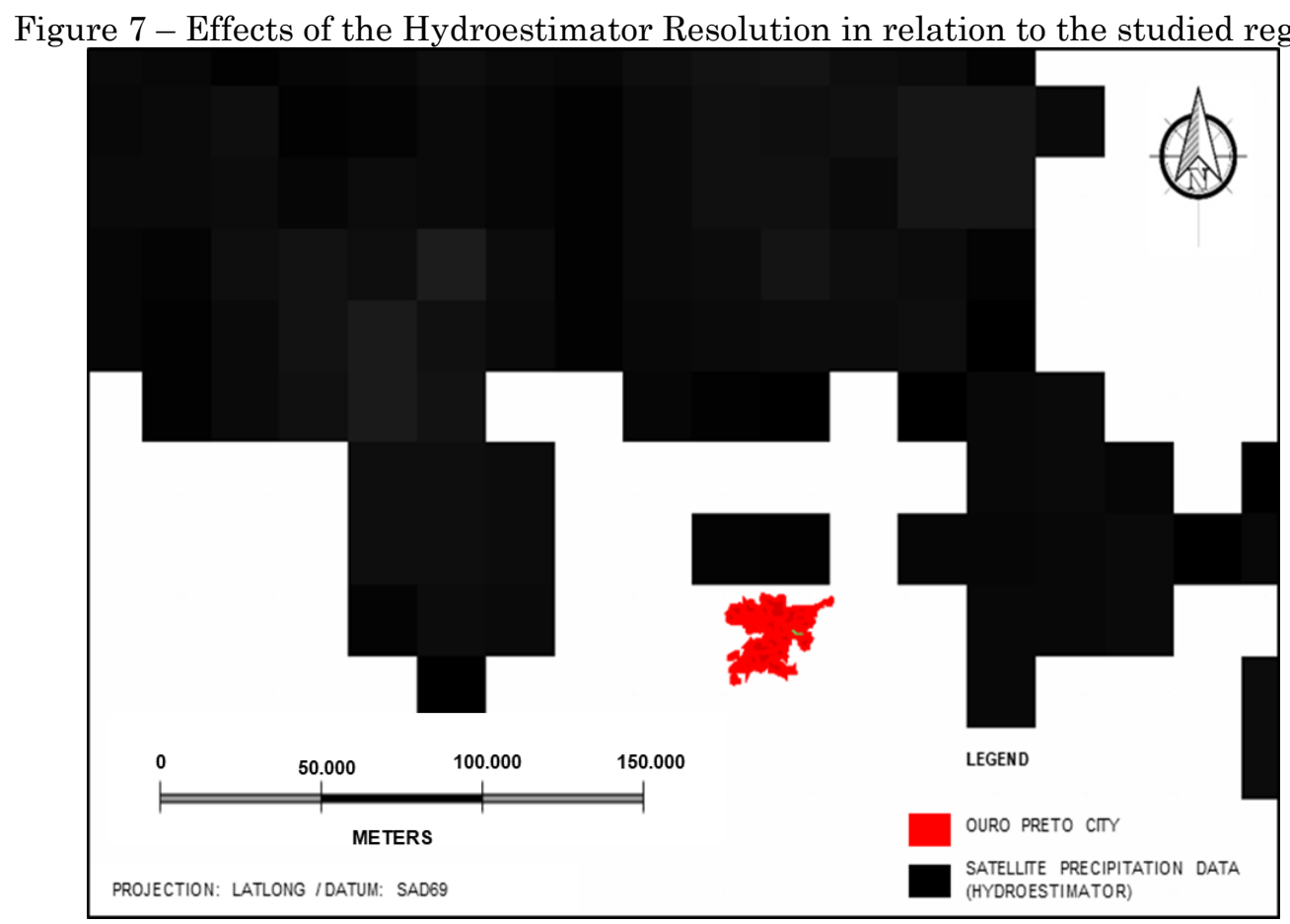

Source: Elaborated by the authors.

Thus, the results obtained by the models, considering the DCP data, are more adequate than those obtained by the hydroestimator. This is 
because DCP data are more compatible with the study area and consequently more compatible with the events and rainfall generated.

Finally, if the population had access to these warning signs, they could have the chance to evacuate the area and thus prevent the occurrence of fatalities.

\section{Conclusion}

It is unacceptable that geological accidents still make victims in modern societies, especially because today's societies are highly characterized by the use of technological advances. Certainly, there are other variables involved in this problem, such as the acceptance and trust of the population in the authorities issuing warnings. Thus, tools must be precise and accurate, in order to minimize the effects of disasters due to extreme behavior of nature.

As compared to actual events, the interpolation of rainfall data was satisfactory when performing an analysis of the results. In fact, an empirical method was used to calibrate the system, but it presented results well in line with reality.

It should also be noted that the analysis using pluviometers (DCP) present more reliable results than those from the hydrostimulator (GOES satellite). This is due to the fact that the resolution of the precipitation by hydroestimator is too broad when comparing with the studied area and can generate significant false-positive rates.

For a broader approach to the potential of the presented system, other variables can be considered, such as hydrogeological parameters, as well as the continuous evaluation of the time series of precipitation data, in order to avoid false warnings. The issuance of these false alerts can be costly to the population; therefore, the alert must be as close as possible to reality. 


\section{Acknowledgements}

The authors thank the National Council for Scientific and Technological Development $(\mathrm{CNPq})$ for financial support, The National Institute of Space Research-INPE, Civil Defense of Ouro Preto, especially Charles Romazamu Murta and Naiara de Lima Silva for the available data.

\section{References}

BARBOSA, H. A.; SILVA, M.; SANTOS, A. M.; NETO, C. P. S. A step beyond visualization: how to ingest meteosat second generation satellite data and products into McIDAS-V, ILWIS AND TerraMA2. Journal of Hyperspectral Remote Sensing, vol. 04, n. 01, 2014, pp. 1-15.

DAI, F.C.; LEE, C.F. Frequency-volume relation and prediction of rainfall-induced landslides. Engineering Geology, vol. 59, 2001, pp. 253-266.

DIAS, L. R. P. T.; FONSECA, A. V.; COUTINHO, R. Q. Identificação de Áreas Suscetíveis a Deslizamento de Terra utilizando Sistema de Informações Geográficas. Dissertação de Mestrado. Universidade Federal da Bahia, Programa de Pós-Graduação em Engenharia Ambiental Urbana, Salvador, 2006. 93p.

INPE. Centro de Previsão de Tempo e Estudos Climáticos (CPTEC). Site $<$ http://www.cptec.inpe.br/>, acessado em setembro de 2015.

INTRIERI, E.; GIGLI, G.; MUGNAI, F.; FANTI, R.; CASAGLI, N. Design and implementation of a landslide early warning system. Engineering Geology, vol. 147-148, 2012, pp. 124-136.

LOPES, E. S. S.; NAMIKAWA, L. M.; REIS, J. B. C. Risco de escorregamento: monitoramento e alerta de áreas urbanas nos municípios no entorno de Angra dos Reis - Rio de Janeiro. Proceedings $13^{\circ}$ Congresso Brasileiro de Geologia de Engenharia e Ambiental, São Paulo. 2011. pp. 1-9.

MEGA CIDADES. Cenários de risco e vulnerabilidades associadas a deslizamentos. Site <http://megacidades.ccst.inpe.br/sao_paulo/VRMSP/capitulo7.php>, acessado em outubro de 2015. 
ONUBR. Nações Unidas no Brasil. ONU: Brasil está entre os 10 países com maior número de afetados por desastres nos últimos 20 anos. Site $<$ https://nacoesunidas.org/onu-brasil-esta-entre-os-10-paises-com-maiornumero-de-afetados-por-desastres-nos-ultimos-20-anos/>, acessado em junho de 2016.

PICIULLO, L.; CALVELLO, M.; CEPEDA, J. M. Territorial early warning systems for rainfall-induced landslides. Elsevier, vol. 179, 2018, pp. 228-247.

PREFEITURA DE OURO PRETO. Alerta Metereológico: Ouro Preto em estado de alerta. Site <http://www.ouropreto.mg.gov.br/alerta-meteorologico/92/ouropreto-em-estado-de-alerta>, acessado em abril de 2016.

RAMOS, R. C.; PEREIRA, M. A.; OLIVEIRA, T. M.; PITANGA, H. N. Computational System for Monitoring and Risk Analysis Based on TerraMA2. Proceedings XVIII Brazilian Symposium on Geoinformatics, Salvador, 2017. pp. 169180.

REIS, J. B. C. Monitoramento e Alerta de Inundação no Município de Itajubá (MG) através de Modelos Matemáticos. Dissertação de Mestrado. Universidade Federal de Itajubá, Programa de Pós-Graduação em Meio Ambiente e Recursos Hídricos, Itajubá, 2014. 82p.

REIS, J. B. C.; CORDEIRO, T. L.; LOPES, E. S. S. Utilização do Sistema de Monitoramento e Alerta de Desastres Naturais aplicado a situações de escorregamento - caso de Angra dos Reis. Proceedings $14^{\circ}$ Simpósio Brasileiro de Geografia Física Aplicada, Dourados/MS, 2011.

REIS, J. B. C.; SANTOS, T. B.; LOPES, E. S. S. Monitoramento em tempo real de eventos extremos na Região Metropolitana de São Paulo - uma aplicação com o SISMADEN. Proceedings $14^{\circ}$ Simpósio Brasileiro de Geografia Física Aplicada, Dourados/MS, 2011.

SALCIARINI, D.; GODT, J. W.; SAVAGE, W. Z.; BAUM, R. L.; CONVERSINI, P. Modeling landslide recurrence in Seattle, Washington, USA. Engineering Geology, vol. 102, 2008, pp. 227-237.

SEGONI, S.; PICIULLO, L.; GARIANO, S. L. Preface: Landslide early warning systems: monitoring systems, rainfall thresholds, warning models, performance evaluation and risk perception. Natural Hazards and Earth System Sciences, vol. 18, 2018, pp. 3179-3186. 
WOLLE, C. M. Análise dos Escorregamentos Translacionais numa Região da Serra do Mar no contexto de uma Classificação de Mecanismos de Instabilização de Encostas. Tese de doutoramento. Universidade de São Paulo, Programa de Pós-Graduação em Engenharia Civil, São Paulo, 1988. 394p. 